\title{
Hollow Fiber Apparatus
}

National Cancer Institute

\section{Source}

National Cancer Institute. Hollow Fiber Apparatus. NCI Thesaurus. Code C19306.

Any apparatus which makes use of hollow fiber technology to increase the yield of surface area-dependent processes, such as dialysis and cell culture of attachmentdependent cells. 